\title{
Botanic Origin, Various Physicochemical and Antioxidant Properties of Honey Samples From Giresun, Turkey
}

\author{
Giresun-Türkiye'den Toplanan Bal Örneklerinin Bitkisel Kökeni, \\ Fizikokimyasal ve Antioksidan Özellikleri
}

\author{
Research Article \\ İlginç Kızılpınar Temizer ${ }^{1}$, Aytaç Güder ${ }^{1}$, Ömür Gençay Çelemli2* \\ ${ }^{1}$ Giresun University, Vocational School of Health, Güre, Giresun, Turkey. \\ ${ }^{2}$ Hacettepe University, Department of Biology, Beytepe, Ankara, Turkey.
}

\begin{abstract}
A B S T R AC T
$\mathrm{T}$

- he aim of the present study is to evaluate the botanic origin, various pysicochemical parameters ( $\mathrm{pH}$, moisture, hydroxymethylfurfural (HMF), fructose/glucose ratio) and antioxidant properties of the four honey samples colected from Giresun-Black Sea Region of Turkey. According to the mellisopalynological analyis, two of the investigated honey samples were determined as Castanea sativa honey and the other two samples were determined as multifloral honeys. The $\mathrm{pH}$ value of honey samples were found between 3.11 and 4.44 . The moisture ot the investigted samples were varied between $11.59-14.13 \%$. The fructose contents of the samples were found between 36.58 and $43.42 \mathrm{~g} / 100 \mathrm{~g}$ and glucose values as 24.84-33.55 g/100 g. HMF values were $1.6 \pm 1.0 \mathrm{mg} / \mathrm{kg}$ for Castanea sativa honeys and $0.65 \pm 0.66 \mathrm{mg} / \mathrm{kg}$ for multifloral honeys. Total phenol contents were high for Castanea sativa honeys compare to two multifloral honeys but total flavonoid content is found as highest in sample 3 (multifloral honey).
\end{abstract}

\section{Key Words}

Antioxidant properties, botanic origin, pysicochemical parameters, total phenolic content, total flavanoid content.

\section{ÖZET}

u çalışmanın amacı Türkiye'nin Giresun-Karadeniz Bölgesi'nden toplanan dört bal örneğinin bitkisel kökeni, fizikokimyasal parametreleri ( $\mathrm{pH}$, nem, hidroksimetilfurfural, früktoz/glukoz oranı) ve antioksidan özelliklerinin değerlendirilmesidir. Palinolojik analizlere göre, incelenen iki örnek Castanea sativa balı diğer ikisi de multifloral bal olarak tanımlanmıştır. Bal örneklerinin pH değerleri 3.11 ve 4.4 aralığında bulunmuştur. Nem değerleri ise \%11.59-14.13 aralığındadır. Örneklerin früktoz içerikleri 36.58 ve 43.42 g/100 g aralığında ve glukoz içerikleri ise 24.84-33.55 g/100 g aralığında bulunmuştur. Castanea sativa ballarının HMF değerleri $1.6 \pm 1.0 \mathrm{mg} / \mathrm{kg}$, multifloral balların ise $0.65 \pm 0.66 \mathrm{mg} / \mathrm{kg}$ olarak bulunmuştur. Castanea sativa ballarının toplam fenol miktarları multifloral ballara oranla yüksek çıkmıştır. Toplam flavonoid miktarları ise 3 numaralı örnekte en yüksek oranda bulunmuştur.

\section{Anahtar Kelimeler}

Antioksidan özellik, botanik köken, fizikokimyasal parametre, toplam fenolik içerik, toplam flavanoid içerik.

Article History: Received: Dec 30, 2015; Revised: May 15, 2016; Accepted: Jun 20, 2016; Available Online: Jul $31,2016$.

DOI: 10.15671/HJBC.20164420563

Correspondence to: Ö.G. Çelemli, Department of Biology, Hacettepe University, Ankara, Turkey. 


\section{INTRODUCTION}

oney is a supersaturated solution of sugars, of which fructose and glucose are the main contributors, with phenolic compounds, minerals, proteins, free amino acids, enzymes, and vitamins acting as minor components $[1,2]$.

Honey is widely consumed by people of the world. It contains numerous health promoting flavonoids and phenolic acids that have proven benefits against disease [2]. Its characteristic is depending mainly on the floral source and also other external factors, including seasonal and environmental factors as well as processing [ 1 3-5]. The physicochemical parameters of honey are defined by the EC Directive 2001/110 [6] The certain parameters are moisture content electrical conductivity, ash content, reducing and non-reducing sugars, free acidity, diastase activity and hydroxymethylfurfural (HMF) and antioxidant content. In this study, we aimed to determined quality of honeys from Giresun regions so we studied botanic origin, physicochemical parameters, phenol and flavonoid contents, free radical scavening and hydrogen peroxide activity.

\section{MATERIAL AND METHODS}

\section{Melissopalynological analysis}

Preparation of honey sample for pollen identification was performed according to the method described by Louveaux et al [7]. Besides the determination of botanical origin, the total pollen number (TPN) of all samples were calculated according to Moar [8]. Distribution (\%) of the honey samples according to Maurizio's classes [9] , Group I (<20000) pollen grains per $10 \mathrm{~g}$ honey), Group II (20000-100000 pollen grains per $10 \mathrm{~g}$ honey), Group III (100.000-500.000 grains per 10 g honey), Group IV (500.000 -1.000 .000 grains per $10 \mathrm{~g}$ honey), Group V (>1.000.000 grains per $10 \mathrm{~g}$ honey).

\section{Physicochemical Characterization of Honey pH}

A pH meter (Ohaus, Starter 3100, USA) was used to measure the $\mathrm{pH}$ of a $10 \%(\mathrm{w} / \mathrm{v})$ solution of honey prepared in distilled water.

\section{Moisture}

Moisture analyses were done by a portable refractometer and determines as \% ratio.

\section{Sugar Analysis by High Performance Liquid Chromatography}

The sugar analysis were done by High Performance Liquid Chromatography (HPLC) with RID dedector and by using a carbohydrate column [10].

\section{Determination of HMF by High Performance Liquid Chromatography (HPLC)}

The samples analysed by High Performance Liquid chromatography with UV detector and with C18-reversed phase column.

\section{Antioxidant Analyses}

Determination of total flavonoid contents (TFC)

The total flavonoids contents of the extracts were determined according to the colorimetric method described by Chung et al [11] with minor modifications. Sample solutions $(0.5 \mathrm{~mL})$ were added to a tube containing $1.5 \mathrm{~mL}$ of absolute ethanol. To the mixture was added subsequently $\mathrm{AlCl}_{3} \cdot 6 \mathrm{H}_{2} \mathrm{O}$ solution $(0.1 \mathrm{~mL}, 10.0 \%)$ and potassium acetate $\left(0.1 \mathrm{~mL}, 1.0 \mathrm{~mol}^{-1}\right)$. Distilled water was added to bring the total volume to $5.0 \mathrm{~mL}$ and the absorbance was read after $30 \mathrm{~min}$ at 415 nm (Optizen Pop UV/Vis Single Beam). Total flavonoids contents were expressed as microgram of catechin equivalent that was obtained from standard graph $\left(R^{2}=0.9979\right)$.

\section{Determination of Total Phenolic Contents (TPC)} Total phenolic contents of samples were analyzed by the Folin \& Ciocalteu's phenol reagent (Folin C) colorimetric method described by Slinkard and Singleton [12]. Sample solutions $(0.5 \mathrm{~mL})$ was mixed with $7.0 \mathrm{~mL}$ of distilled water and subsequently with Folin $\mathrm{C}$ reagent $(0.5 \mathrm{~mL})$. After $3 \mathrm{~min}, \mathrm{Na}_{2} \mathrm{CO}_{3}$ solution $(3.0 \mathrm{~mL}, 2.0 \%$ ) was added into the mixture. The color developed for 1 hour and the absorbance was measured at $760 \mathrm{~nm}$ in a spectrophotometer (Optizen Pop UV/Vis Single Beam). Gallic acid was used as the standard, and total phenolic content was expressed as microgram of gallic acid equivalent by using an equation that was obtained from standard gallic acid graph $\left(R^{2}=0.9995\right)$. 
Determination of 2,2-diphenyl-1-picrylhydrazyl (DPPH) Free Radical Scavenging Activity

The DPPH radical scavenging activities were studied by following a previous report with slowly modified [13]. Serially diluted samples $(3.0 \mathrm{~mL})$ at the different concentrations $(10-100 \mu \mathrm{g} / \mathrm{mL})$ were added to DPPH solutions ( $1.0 \mathrm{~mL}, 0.2 \mathrm{mM}$ ) in ethanol. The mixtures were shaken forcefully and allowed to sit at room temperature for 30 min. Then, absorbance was recorded at $517 \mathrm{~nm}$ by using a spectrophotometer (Optizen Pop UV/ $V$ is Single Beam) and the results were expressed as $\mathrm{SC}_{50}(\mu \mathrm{g} / \mathrm{mL})$ by linear regression analysis and represent mean of the data.

\section{Determination of Hydrogen Peroxide Scavenging Activity}

The hydrogen peroxide scavenging activity was assayed according to the medhod described by Ruch et al [14]. Briefly, the samples were dissolved in $0.04 \mathrm{M}$ phosphate buffer $(\mathrm{pH}=7.4)$ and $3.4 \mathrm{~mL}$ of the samples were mixed with $0.6 \mathrm{~mL}$ of $40 \mathrm{mM}$ $\mathrm{H}_{2} \mathrm{O}_{2}$ solution (prepared in the same buffer). The absorbance of the mixture was measured at 230 $\mathrm{nm}$ versus blind sample after 10 min with UV/VIS spectrophotometer (Optizen, Korea). Phosphate buffer without hydrogen peroxide used as blank. The decrease in absorbance value showed the high level of hydrogen peroxide scavenging activity designation. The results were expressed as $\mathrm{SC}_{50}$ values $(\mu \mathrm{g} / \mathrm{mL})$.

\section{Statistical Analysis}

Experimental results were given as mean \pm S.D. of the three paralel measurements. $P$ values of $<$ 0.05 were regarded as significant and $P$ values of $<0.01$ were regarded as very significant.

\section{RESULTS AND DISCUSSION}

Four honey samples were tested in this study in order to assess their floral origin, some physicochemical characterization $(\mathrm{pH}$, moisture, fructose and glucose content, F/G hydroxmethylfurfural content) and various antioxidant properties.

\section{Melissopalynological analysis}

Honey sample 2 and 4 are unifloral because they contained a predominant pollen-type (frequency
45\%) and are classed as Castanea sativa honey. Other honey samples (1 and 3 ) are multifloral because no dominant pollen was found. The pollen analysis showed the main botanical species for the investigated samples are $C$. sativa and Fabaceae species. Table 1 shows pollens belong to taxa and percentage distribution. Honey samples classified with TPN 10 values. Sample 1 and 3 were found in Group 1, Sample 2 and 4 were found in Group 2.

\section{Physicochemical Characterization of Honey pH}

The $\mathrm{pH}$ of honey samples varied between 3.22 and 4.44. These results are similar to those obtained by Giorgi et al [15] for honey samples from Valcamonica valley of the Lombardia region. Atanassova et al [16] found $\mathrm{pH} 5.65$ for $C$. sativa honey from Bulgaria. Fallico et al [17] found $\mathrm{pH}$ 5.9 Sicilian C.sativa honey, our Castanea honey samples are more asidic. Our results were lower than the $\mathrm{pH}$ range 4.50-5.64 declared by Ünal and Küplülü [18], Derebasi et al [19] for Turkish honey. Our honey samples are more asidic. The $\mathrm{pH}$ values of honey are of great importance during extraction and storage, since acidity can influence the texture, stability, and shelf life of honey [20].

\section{Moisture}

Moisture is one of the most important factor to be considered as a quality parameter of honey. The moisture content in the investigated honey samples was found to be $11.59-14.13 \%$ (Table 2), which are within the limit ( $\leq 20 \%)$ recommended by the international quality regulations (2001). These findings similar to those obtained by reported by Ünal and Küplülü [18]. Derebasi et al [19], for Turkish honey (12.08-25).

\section{Sugar Content}

Honey consists of a mixture of sugars, mostly glucose and fructose [21]. The results of the sugar analysis of all the four honey samples showed Table 2. The fructose contents of the samples varied between 36.58 and $43.42 \mathrm{~g} / 100 \mathrm{~g}$. The glucose contents of the samples were within a range of 24.84 to $33.55 \mathrm{~g} / 100 \mathrm{~g}$. These findings are in agreement with those reported by Buba et al [22] and Ciappini et al who [23], found similar range of the fructose and glucose contents for the samples. 
Table 1. Pollen types recovered from the honey samples and their frequency (\%).

\begin{tabular}{|c|c|c|c|c|c|c|c|c|c|}
\hline Samples & Apiaceae & Asteraceae & C.sativa & Fabaceae & Lamiaceae & Rosaceae & Rhododendron & Taraxacum & Undefinied \\
\hline 1 & 5.88 & 2.94 & 23.53 & 32.35 & 5.88 & 17.65 & 11.76 & & \\
\hline 2 & & & 65.48 & 19.05 & 0.6 & 0.6 & 14.29 & & \\
\hline 3 & & & 44.29 & 26.43 & 0.71 & 6.43 & 18.57 & 3.57 & \\
\hline 4 & & 1.16 & 96.53 & 1.16 & & 0.58 & & & 0.58 \\
\hline
\end{tabular}

Table 2. The results of the analysis of physicochemical parameters.

\begin{tabular}{|c|c|c|c|c|c|c|c|}
\hline Samples & $\mathrm{pH}$ & $\begin{array}{c}\text { Moisture } \\
\text { (\%) }\end{array}$ & $\begin{array}{l}\text { Fructose } \\
(\mathrm{g} / 100 \mathrm{~g})\end{array}$ & $\begin{array}{l}\text { Glucose } \\
(g / 100 \mathrm{~g})\end{array}$ & $\begin{array}{c}F / G \\
(g / 100 \mathrm{~g})\end{array}$ & Total F+G & $\begin{array}{c}\text { HMF } \\
(\mathrm{mg} / \mathrm{kg})\end{array}$ \\
\hline 1 & 3.22 & 16.2 & 43.42 & 31.53 & 1.34 & 74.95 & 2.31 \\
\hline 2 & 4.44 & 17.4 & 40.9 & 33.55 & 1.21 & 74.45 & 1.11 \\
\hline 3 & 4.08 & 16.5 & 36.58 & 24.84 & 1.47 & 61.42 & 0.18 \\
\hline 4 & 4.34 & 15.7 & 39.51 & 26.07 & 1.5 & 65.58 & 0.89 \\
\hline
\end{tabular}

$\mathrm{F}+\mathrm{G}$ levels in this study are ranged between 61.42 and 74.95. Fructose and glucose are the dominant sugar types in honeys, which although no limits have been fixed for their individual values, their sum (Fructose+glucose) has been fixed at a value of $\geq 60 \mathrm{~g} / 100 \mathrm{~g}$ as one of the requirements of the international standard for honey established by Codex Alimentarius Commission. The total content of glucose and fructose is over $60 \mathrm{~g} / 100$ $\mathrm{g}$ of honey for all samples (Table 2).

Can et al [24] were found glucose contents $19.35 \pm 3.00 \mathrm{~g} / 100 \mathrm{~g}$, fructose contents $38.44 \pm 2.72$ $\mathrm{g} / 100 \mathrm{~g}$ ranged between in 7 chestnut honeys. They found 7 multifloral honey's glucose contents average $25.07 \pm 6.59 \mathrm{~g} / 100 \mathrm{~g}$, fructose contents average $32.35 \pm 5.65 \mathrm{~g} / 100 \mathrm{~g}$. The fructose/ glucose ratio were within the range of 1.21 to 1.5 [24]. We found in this study that the fructose contents average are $41.47 \pm 2.8 \mathrm{~g} / 100 \mathrm{~g}$, glucose contents average $28.8 \pm 3.86 \mathrm{~g} / 100 \mathrm{~g}$ for chestnut honey, fructose contents average $38.74 \pm 3.05$ $\mathrm{g} / 100 \mathrm{~g}$, glucose contents average $29.19 \pm 6.16$ $\mathrm{g} / 100 \mathrm{~g}$ for multifloral honeys. Our results are a bit higher than these results.

Honey's Sugar Composition Depends on the Floral and Region Origin $[25,26]$. F/G ratio are being used for the prediction of honey crystallization. Honey crystallization is slower when the $F / G$ ratio is more than 1.3 and it is faster when the ratio is below 1.0 [27]. According to these findings the crystalization will be slower for all investigated samples.

\section{HMF}

HMF or 5-hydroxymethyl- 2-furaldehyde, is an organic compound obtained from sugars like fructose, cellulose, inulin and starch [28]. HMF content is widely recognized as a parameter that indicates the freshness of honey [29]. High concentrations of HMF in honey are an indicator of overheating and storage in poor conditions [30]. The European Union [6] established that the highest allowed amount of HMF in honey should be $40 \mathrm{ppm}$, with the exception of honeys of tropical origin (80 ppm). The obtained results were all lower than today legal limits (Table 2). In this study, we found HMF contents average as $1.6 \pm$ $1.0 \mathrm{mg} / \mathrm{kg}$ for $C$. sativa honeys and, $0.65 \pm 0.66$ $\mathrm{mg} / \mathrm{kg}$ for multifloral honeys. Can et al [24] found HMF contents as $9.28 \pm 7.13 \mathrm{mg} / \mathrm{kg}$ for chestnut honey, $14.71 \pm 12.10 \mathrm{mg} / \mathrm{kg}$ for multifloral honeys. Our results are lower than these results. Fallico et al [17] examined four different Sicilian honeys and they determined that HMF wasn't detectable in Chestnut honeys before the heating treatment. This is supported by our own research findings. Our all honey samples have very little HMF levels so several factors influence the formation of HMF in honey: temperature and time of heating [31], storage conditions; use of metallic containers [32] and the chemical properties of honey, which are related to the floral source. 
Table 3. The results of the analysis of Total Flavonoid, Total Phenol, DPPH and $\mathrm{H}_{2} \mathrm{O}_{2}$ of samples.

\begin{tabular}{ccccc}
\hline Samples & $\begin{array}{c}\text { Total Flavonoid } \\
(\mathbf{m g ~ C A E} / \mathbf{1 0 0} \mathbf{g})\end{array}$ & $\begin{array}{c}\text { Total Phenol } \\
(\mathbf{m g ~ G A E} / \mathbf{1 0 0} \mathbf{~ g})\end{array}$ & $\begin{array}{c}\mathrm{DPPH} \\
\mathbf{S C}_{\mathbf{5 0}}(\mu \mathbf{g} / \mathbf{m L})\end{array}$ & $\begin{array}{c}\mathbf{H}_{\mathbf{2}} \mathbf{O}_{\mathbf{2}} \\
\mathbf{S C}_{\mathbf{5 0}}(\mu \mathbf{g} / \mathbf{m L})\end{array}$ \\
\hline $\mathbf{1}$ & 0.29 & 4.48 & 71.92 & 122.48 \\
\hline $\mathbf{2}$ & 0.99 & 7.51 & 39.77 & 83.72 \\
\hline $\mathbf{3}$ & 2.49 & 5.49 & 39.77 & 220.46 \\
\hline $\mathbf{4}$ & 1.08 & 8.01 & 19.04 & 22.69 \\
\hline
\end{tabular}

\section{Antioxidant Analyses Total Flavonoid Content}

Total flavonoid content of the honey samples varied between 0.29-2.49 mg CAE/100 g (Table 3). The highest value was determined in honey sample 3 multifloral honey but the chestnut pollen is considerably high compare to the other pollen. The sample 4 and 2 follow this sample. However, the lowest value was observed in honey sample 1. Flavonoids contents varied with the origin of honey samples and ranged from 0.93 $\mathrm{mg} \mathrm{CAE} / 100 \mathrm{~g}$ (Jordan Valley) to $4.6 \mathrm{mg} \mathrm{CAE} / 100$ g (Umm Alyanabea) [33]. Flavonoid content of Litchi Honey Procured from Gazipur and Tangail District, Bangladesh varied between 4.024 and 4.954 mg Catechin/100 g [34]. Our results were lower values compared with these results.

\section{Total phenolic content}

Total phenolics were highest $8.01 \mathrm{mg}$ GAE/100 $\mathrm{g}$ in the sample 4 and lowest $4.48 \mathrm{mg} \mathrm{GAE} / 100$ $\mathrm{g}$ in the sample 1 (Table 3). Lachman et al [35] declared that total phenolics were ranged from $3.92 \mathrm{mg} \mathrm{CAE} / 100 \mathrm{~g}$ (multifloral honey) to $16.71 \mathrm{mg}$ CAE/100 g (honeydew honey). Our results are in these range. Ertürk et al [36] declared that the total phenol content of honeys from east blacksea region was found in the range of 0.058 to 0.396 $\mathrm{mg} \mathrm{GAE} / \mathrm{g}$, which was determined using gallic acid as standard $\left(R^{2}=0.997\right)$. Our results are similar to the results of this study. Total phenolic content of chestnut honeys (sample 2,4) are found higher compared to the multifloral honeys.

\section{DPPH Free Radical Scavenging Activity and Hydrogen Peroxide Scavenging Activity}

DPPH free radical and hydrogen peroxide scavenging activities of four honey are in the range of 19.04-71.92 and 22.69-220.46 respectively as $\mathrm{SC}_{50}$ values $(\mu \mathrm{g} / \mathrm{mL})$. While the sample 4 has highest DPPH Free Radical Scavenging Activity, sample 1 has the lowest activity (Table 3 ). Ertürk et al [36] declared that the honeys of East Black Sea has a value of '29.388-458.450 (mg/mL)' DPPH Free Radical Scavenging activity. Sarıkaya et al [37] determined the Free Radical Scavenging Activities of honey and pollen samples as '5.7 $\pm 0.4-9.0 \pm 0.7$ ' that collected from Zonguldak (Turkey). While The highest hydrogen peroxide removing activity was found in sample 4, the lowest activity is sample 2 .

\section{CONCLUSION}

The investigated honey samples showed different levels of flavonoids and phenolics, which role as effective natural antioxidants. Among the studied honeys, C. sativa honey presented total phenol content and hydrogen peroxide removing activity. The important influence of the botanical origin on the pysicochemical and antioxidant properties of honey was confirmed by the variability of the studied parameters.

\section{ACKNOWLEDGEMENT}

We would like to thank Giresun University's Scientific Research Unit (Project No. FEN-BAP-A-220413-56) for the financial support.

\section{Funding}

This research was supported by Giresun University's Scientific Research Unit (Project No. FEN-BAP-A- 220413 56) for the financial support.

\section{References}

1. E. Anklam, A review of the analytical methods to determine the geographical and botanical origin of honey, Food Chem., 63 (1998) 549-562.

2. J.M. Alvarez-Suarez, S. Tulipani, S. Romandini, E. Bertoli, M. Battino, Contribution of honey in nutrition and human health: a review, Mediterranean Journal of Nutrition and Metabolism, 3 (2010), 15-23. 
3. A. Islam, I. Khalil, N. Islam, M. Moniruzzaman, A. Mottalib, S.A. Sulaiman, S.H. Gan, Physicochemical and antioxidant properties of Bangladeshi honeys stored for more than one year, BMC Complem. M. Altern., 12 (2012) 177.

4. D. Arreaz-Roman, A.M. Gomez-Caravaca, M. GomezRomero, A. Segura-Carretero,. A. FernandezGutierrez, Identification of phenolic compounds in rosemary honey using solid-phase extraction by capillary electrophoresis-electrospray ionizationmass spectrometry, J. Pharm. Biomed. Anal., 41 (2006) 1648-1656.

5. A. Perna, A. Simonetti, I. Intaglietta, A. Sofo, E. Gambacorta, Metal content of southern Italy honey of different botanical origins and its correlation with polyphenol content and antioxidant activity, Int. J. Food Sci. Tech., 47 (2012) 1909-1917.

6. EU DIRECTIVE /110/2001 of 02/12/2001 (L 10/47).

7. J. Louveaux, A. Maurizio, G. Vorwohl, 1978. Methods of melissopalynology, Bee World, 59 (1978) 139-153.

8. N. Moar, Pollen analysis of New Zealand honey, New Zea.I J. Agr. Res., 28 (1986) 39-70.

9. A. Maurizio, Microscopy of honey, In Crane, E (Ed). Honey, a comprehensive survey (2nd edition). Heinemann; London, UK., (1975) 240-257 pp.

10. IHC, 2002, International Honey Commission-IHC. (2002) Swiss Bee Research Centre, FAM, Liebefeld, $\mathrm{CH}-3003$ Bern, Switzerland.

11. Y.C. Chung, C.T. Chang, W.W. Chao, C.F. Lin, S.T. Chou, Antioxidative activity and safety of the $50 \%$ ethanolic extract from red bean fermented by Bacillus subtilis IMR-NK1, J. Agric. Food Chem., 50 (2002) 2454-2458.

12. K. Slinkard, V.L. Singleton, Total phenol analyses: automation and comparison with manual methods, Am. J. Enol. Viticult., 28 (1977) 49-55.

13. M.S. Blois, Antioxidant determinations by the use of a stable free radical, Nature, 181 (1958) 1199-1200.

14. R.J. Ruch, S.J. Cheng, J.E. Klaunig, Prevention of cytotoxicity and inhibition of intracellular communication by antioxidant catechins isolated from Chinese green tea, Carcinogenesis, 10 (1989), 1003-1008.

15. A. Giorgi, M. Madeo, J.Baumgartner, G.C. Lozzia, The relationships between phenolic content, pollen diversity, physicochemical information and radical scavenging activity in honey, Molecules, 16 (2011) 336-347.

16. J. Atanassova, L. Yurukova, M. Lazarova, Pollen and inorganic characteristics of Bulgarian unifloral honeys, J. Czech. Sci. Food, 30 (2012) 520-526.

17. B. Fallico, M. Zappalà, E. Arena, A. Verzera, Effects of conditioning on HMF content in unifloral honeys, Food Chem., 85 (2004) 305-313.

18. C. Ünal, Ö. Küplülü, Chemical quality of strained honey consumed in Ankara, Ankara Üniv. Vet. Fak. Derg, 53 (2006) 1-4

19. E. Derebasi, G. Bulut, M. Col, F. Guney, N. Yasar, O. Erturk, Physicochemical and residue analysis of honey from Black Sea Region of Turkey, Fresen Environ. Bull., 23 (2014) 10-17.
20. A. Terrab, M.J. Díez, F.J. Heredia, Palynological, physico-chemical and colour characterization of Moroccan honeys: III. Other unifloral honey types, Int. J. Food Sci. Tech., 38 (2003) 395-402.

21. Jr.J.W. White, Physical characteristics of honey. In Crane, E (Ed), In: Honey, a Comprehensive Survey., Heinemann; London, UK., (1975) 207-293.

22. F. Buba, A. Gidado, A. Shugaba, Analysis of biochemical composition of honey samples from North-East Nigeria, Biochem. Anal. Biochem., 2 (2013) 139.

23. M.C. Ciappini, M.B. Gatti, M.V. Di Vito, S. Gattuso, M. Gattuso, Characterization of different floral origins honey samples from Santa Fe (Argentine) by palynological, Physicochemical and Sensory data, Apiacta, 43 (2008) 25-36.

24. Z. Can, O. Yildiz, H. Şahin, E.A. Turumtay, S. Silici, S. Kolayli, An investigation of Turkish honeys: Their physico-chemical properties, antioxidant capacities and phenolic profiles, Food Chem., 180 (2015) 133-41.

25. P. Andrade, F.Ferreres, M.T. Amaral, Analyses of honey phenolic acids by HPLC, its application to honey botanical characterization, J. Liq. R.T. Chromatogr., 20 (1997) 2281-2288.

26. E. Mendes, E.B. Proenca, I.M.P.L.V.O. Ferreira, M.A. Ferreira, Quality evaluation of Portuguese honey, Carbohyd. Polym., 37 (1998) 219-223.

27. Y. Amir, A. Yesli, M.Bengana, R. Sadoudi, T. Amrouche, Physico-chemical and microbiological assessment of honey from Algeria, EJEAFChe., 9 (2010) 1485-1494.

28. Priyadharshini R.D.; Infee sherley, K. Review on production of 5-Hydroxymethylfurfural from carbohydrate rich biomass, International Journal of ChemTech Research, 8 (2015) 704-710.

29. M. Zappalà, B. Fallico, E. Arena, A. Verzera, Methods for the determination of HMF in honey: a comparison, Food Control, 16 (2005) 273-277.

30. M. Moniruzzaman, S.A. Sulaiman, M.I. Khalil, S.H. Gan, Evaluation of physicochemical and antioxidant properties of sourwood and other Malaysian honeys: a comparison with manuka honey, Chem. J Cent., 7 (2013) 1-12.

31. P.K. Bath, N. Singh, A comparison between Helianthus annuus \& Eucalyptus lanceolatus honey, Food Chem. 67 (1999) 389-397.

32. A. Cherchi, M. Porcu, L. Spariedda, C.I.G Tuberoso, Influence of ageing on the quality of honey [Sardinia], Ind. Conserve, 72 (1997) 266-271.

33. T.M. Rababah, M. Al-Omoush, S. Brewer, M. Alhamad, W. Yang, M. Alrababah, A.L.M. Al-Ghzawi, A.M. U'datt, K. Ereifej, F. Alsheyab, R. Esoh, A. Almajwal, Total phenol, antioxidant activity, flavonoids, anthocyanins and color of honey as affected by floral origin found in the arid and semiarid mediterranean areas, J. Food Process. Pres., 38 (2014) 1119-1128.

34. S. Islam, J.S. Jothi, M. Islam, A. Zubair, Antioxidant and physico-chemical properties of Litchi honey procured from gazipur and tangail district, bangladesh, Journal of Entomology and Zoology Studies, 2 (2014) 207-211. 
35. J. Lachman, M. Orsák, A. Hejtmánková, E. Kováová Evaluation of antioxidant activity and total phenolics of selected Czech honeys. Lebensm, Wiss. Technol. 43 (2010) 52-58.

36. Ö. Erturk, H. Şahin, S. Kolayli, M. Çol Ayvaz, Antioxidant and antimicrobial activity of east black sea region honeys, Turk J. Biochem. 39 (2014) 99-106
37. A.O. Sarikaya, E. Ulusoy, N. Öztürk, M. Tunçel, S. Kolayli, Antioxidant activity and phenolic acid constituents of chestnut (Castania sativa Mill.) honey and propolis, J. Food Biochem., 33 (2009) 470-481. 
